http://dx.doi.org/10.18778/8088-220-1.02

\author{
Hanna Zalewska-Jura \\ Uniwersytet Łódzki \\ Katedra Filologii Klasycznej
}

\title{
ELEGIE SOLONA. PRZYKLAD NAJDAWNIEJSZEJ PUBLICYSTYKI POLITYCZNEJ
}

\begin{abstract}
Streszczenie
Najstarsze greckie świadectwa literackie nie potwierdzają trenodycznego charakteru elegii. W zachowanym dorobku archaicznych poetów znajdują się utwory o tematyce bitewnej, miłosnej, parenetycznej, dydaktycznej, filozoficznej. W tę różnorodność treściową wpisuje się elegia publicystyczna Solona. Jego twórczość poetycka w głównej mierze jest związana z aktywnością w życiu społeczno-politycznym Aten VII/VI wieku p.n.e. Część wprowadzonych przez Solona reform, zmierzających do likwidacji głębokiego kryzysu wewnętrznego ateńskiej polis, nie spotkało się z akceptacją grup społecznych zaangażowanych w konflikt. Twórczość poetycka, w tym także elegijna, tego męża stanu stała się polem publicystycznej dyskusji z przeciwnikami politycznymi, a jego utwory instrumentem propagandy społecznej.
\end{abstract}

Słowa kluczowe: Solon, reformy Solona, elegia grecka, publicystyka

\section{Summary}

Solon's elegy as an example of ancient political propaganda

The earliest texts written in ancient Greek language do not confirm mourning character of ancient elegy. Among the oldest surviving works of archaic period poets there are texts that focus on military, amatory, parenetic, didactic or philosophical themes. Solon's works on social and political subjects may be also included in that miscellany of issues. Solon's literary works result from his active participation within political and social community of Athens in the VII-VI centuries B. C. Some of his reforms to legislate against political, economic, and moral decline in archaic polis failed in the short term as they were not approved by the Athenians engaged in the conflict. Therefore his poetry became a way to defend his constitutional, economic and moral reforms and beliefs against political opponents. Thus, Solon's elegy may be regarded an instrument of social and political discussion written not for pleasure but rather as patriotic propaganda.

Keywords: Solon, Solon's reform, the Greek elegy, political propaganda

Solon (ok. 640-559 p.n.e.), którego potomność zaliczyła do elitarnego grona siedmiu mędrców, na kartach historii powszechnej zapisał się jako mąż stanu i prawodawca ateński, do historii literatury natomiast przeszedł jako jeden z greckich poetów elegijnych epoki archaicznej. Te dwa aspekty aktywności Solona 
- polityka i poezja - pozwolą umiejscowić jego twórczość na płaszczyźnie problematyki zakreślonej w tytule. Dla zachowania klarowności wywodu wypada odwołać się do niezbędnych preliminariów natury historycznej i historyczno-literackiej; pierwsze dotyczą sytuacji społeczno-politycznej w Atenach na przełomie VII i VI wieku p.n.e., drugie wiążą się z charakterem archaicznej elegii, odmiennym od nowożytnego. Należy jednak zaznaczyć, że gwoli uzupełnienia źródłowego corpus, przychodzi sięgnąć także do utworów jambicznych, które znalazły się w dorobku Solona, pozwalając mu w duchu polemicznym wyrazić treści związane z aktualną sytuacją ${ }^{1}$.

\section{Sytuacja wewnętrzna w Atenach przed reformami Solona}

W VII wieku p.n.e. cała władza i wielka część majątków ziemskich znajdowała się w rękach nielicznej grupy przedstawicieli starej arystokracji rodowej - eupatrydów („dobrze urodzonych”). Taka sytuacja wcześniej czy później musiała spowodować niezadowolenie pozostałych warstw społeczeństwa attyckiego. Zależni od eupatrydów chłopi, którzy uprawiali ich ziemie w zamian za szóstą część plonów, tak zwani hektemoroi ${ }^{2}$, domagali się zmiany swojego statusu i być może nadziału gruntów. W gorszym położeniu znaleźli się niezależni chłopi, spośród których wielu, nie mogąc utrzymać się z małych poletek, zaciągało u arystokratów wysokooprocentowane długi pod zastaw ziemi, a często pod zastaw wolności osobistej. Symboliczną oznaką zajęcia przez wierzycieli pola zrujnowanego rolnika były kamienne słupy dłużnicze, tak zwane horoi. Sami bankruci natomiast $\mathrm{w}$ najlepszym wypadku stawali się hektemoroi, w najgorszym - popadali w niewolę i byli sprzedawani poza granice Attyki, ponieważ, zgodnie z obyczajem, nie można było stać się niewolnikiem w ojczystej polis. Przejmowanie przez eupatrydów ziemi w wyniku zadłużenia chłopów doprowadziło do kryzysu agrarnego, który miał negatywny wpływ na politykę wewnętrzną i zagraniczną Aten. Niechętni arystokratom byli też drobni posiadacze ziemi, zagrożeni utratą względnej stabilizacji ekonomicznej i pozycji społecznej. Wreszcie politycznemu monopo-

1 Jak zauważył Jerzy Danielewicz, archaiczne utwory jambiczne, pojmowane w ogólniejszym znaczeniu ze względu na szeroki zakres tematów odnoszących się do ówczesnych aktualiów, zbliżały się charakterem do poezji elegijnej; Liryka starożytnej Grecji, oprac. J. Danielewicz, Wrocław 1984, s. LIX.

2 Interpretacja terminu hektemoroi (dosł. „sześcioczęściowy”) budzi dziś wśród historyków kontrowersje co do tego, czy szóstą część plonów chłopi oddawali właścicielom, czy też stanowiła ona dla nich źródło utrzymania; zob. B. Bravo, E. Wipszycka, Historia starożytnych Greków, t. I, Warszawa 1988, s. 237. Warto zauważyć, że Hesychios, uczony grecki z V wieku n.e., w swoim leksykonie języka greckiego pod hasłem hektemoroi podaje objaśnienie: „ci, którzy uprawiają rolę za szóstą część (scil. plonów)”. 
lowi eupatrydów sprzeciwiali się ci obywatele, którzy dzięki postępom kolonizacyjnym i rozwojowi handlu morskiego dorobili się znacznych majątków i aspirowali do wysokich urzędów państwowych oraz dostępu do władzy.

Wobec narastającego nacisku społecznego arystokracja zmuszona była pójść na pewne ustępstwa, zwłaszcza że przykłady inny greckich poleis wskazywały, iż podobny stan rzeczy nieuchronnie prowadzil do gwałtownych konfliktów wewnętrznych lub do wprowadzenia władzy tyrańskiej przez jakąś ambitną jednostkę, której radykalne i demagogiczne posunięcia mogły zagrozić interesom eupatrydów - tym bardziej że w obrębie tej warstwy między przedstawicielami możnych rodów dochodziło $\mathrm{w}$ walce o prymat do ostrych napięć i krwawych starć $^{3}$.

W 594 r. p.n.e. społeczeństwo ateńskie wybrało Solona na archonta - to najważniejszy urząd w polis - powierzając mu zarazem zadanie przeprowadzenia reform ekonomiczno-społecznych i uzdrowienia polityki wewnętrznej. Plutarch z Cheronei, pisarz grecki z przełomu I i II wieku n.e., autor między innymi dzieła biograficznego Żywoty sławnych mężów, w części poświęconej Solonowi tak uzasadniał wybór Ateńczyków:

Wtedy nierówność biednych wobec bogatych osiągnęła szczyt i miasto znalazło się w skrajnym niebezpieczeństwie. Zdawało się, że tylko przez wprowadzenie tyranii zapanuje w mieście spokój i porządek. Cały lud był dłużnikiem bogatych; bo albo ludzie pracowali na roli jako najemnicy i płacili właścicielom szóstą część uzyskanych plonów (takich zwano szóstakami lub najemnikami), albo brali pożyczki pod zastaw własnej osoby i stawali się dłużnikami u swoich wierzycieli, niektórzy w kraju w roli niewolników, inni sprzedawani zagranicę. Wielu z konieczności sprzedawało nawet własne dzieci (żadne prawo tego nie zabraniało) i uciekało z miasta przed wierzycielami. Tłumy jednak najsilniejszych połączyły się i wzajemnie zachęcały, aby nie przyglądać się bezczynnie, ale aby wybrać jednego godnego zaufania przedstawiciela, uwolnić zadłużonych, przeprowadzić nowy podział ziemi, zmienić ustrój. Wówczas najroztropniejsi z Ateńczyków zgodnie widzieli jedynie w Solonie człowieka wolnego od błędów, który nie ma nic wspólnego z niesprawiedliwością bogaczy ani z przemocą wobec biedaków, i chcieli, aby zajął się sprawami państwa z zażegnał konflikt (13-14).

3 Plutarch w Żywocie Solona relacjonuje wydarzenia o dokonanym przez eupatrydę Kylona zamachu stanu, krwawo stłumionym przez Megaklesa z potężnego rodu Alkmenoidów. Pisarz przypisuje Solonowi udział w zażegnaniu konfliktu: „Kiedy zaś bunt doszedł już do szczytu, wśród ludu doszło do podziału. Wtedy Solon, który już cieszył się dobrym imieniem, wraz ze znacznymi Ateńczykami wystąpił między skłóconych, prośbami i przestrogami skłonił tych nazwanych wyklętymi, by zgodnie z prawem poddali się wyrokowi trzydziestu sędziów wybranych według zasług i znaczenia” (12); J. Wolski, Historia powszechna. Starożytność, Warszawa 1972, s. 185-186. 


\section{Charakter greckiej elegii epoki archaicznej}

Wbrew współczesnym popularnym wyobrażeniom, ukształtowanym przez nowożytne wyróżniki gatunkowe ${ }^{4}$, najdawniejsza elegia grecka nie musiała mieć zawartości trenodycznej. Co więcej, pojawiają się uzasadnione wątpliwości, czy w ogóle istniał taki typ elegii ${ }^{5}$. W utworach Mimnermosa, co prawda, znajdują się nostalgiczne refleksje o przemijaniu czasu i o nieuchronnej starości (na przykład fr. 4-5; 1; 2; 3 West), mają one jednak wymiar raczej erotyczno-hedonistyczny niż egzystencjalno-funeralny. W zachowanym corpus archaicznej poezji elegijnej dominantę stanowią treści bitewne, parenetyczne, filozoficzne, historyczne, sympotyczne, miłosne. W tę różnorodność tematów wpisuje się poetycka publicystyka Solona.

Dla dalszych rozważań istotne są dwie kwestie: 1) sposobu i 2) okoliczności prezentowania utworów elegijnych. Starożytni teoretycy epok poklasycznych odmówili elegii miejsca wśród gatunków lirycznych. O takiej kwalifikacji zadecydowało mylne, jak się dziś wydaje, przekonanie o braku elementów muzycznych towarzyszących wykonaniu 6 . Niewykluczone, że na podobnej opinii zaważyła pragmatyka wykonawcza w późniejszych okresach, czyli melorecytacja ${ }^{7}$ bez akompaniamentu, oraz porównanie $\mathrm{z}$ innymi odmianami melicznymi, odznaczającymi się wyrafinowaną, w porównaniu z elegią, melodyką. Większość współczesnych badaczy natomiast, opierając się interpretacji starożytnych testimoniów, stoi na stanowisku, że archaiczna elegia była formą meliczną, to znaczy śpiewaną przy akompaniamencie aulosów ${ }^{8}$. Przyjęcie tego poglądu implikuje domniemanie, że prezentacja elegii przy wtórze instrumentalnym dotyczyła sytuacji uroczystych, odświętnych lub oficjalnych, wymagała bowiem ze strony wykonawcy,

4 Zob. I. Adamczewska, Elegia, [hasło w:] Słownik rodzajów i gatunków literackich, red. G. Gazda, Warszawa 2012, s. 253-254.

$5 \mathrm{~W}$ zachowanym corpus archaicznej poezji elegijnej nie ma śladu po utworach o czysto lamentacyjnej tematyce; zob. E.L. Bowie, Early Greek Elegy. Symposium and Public Festival, „JHS” 1986, vol. 106, s. 22-25. Status quaestionis omawia Krystyna Bartol; eadem, Greek Elegy and Iambus. Studies in Ancient Literary Sources, Poznań 1993, s. 53-54.

${ }^{6} \mathrm{~K}$. Bartol, Liryka grecka. Wybór tekstów i komentarz, t. I: Jamb i elegia, WarszawaPoznań 1999, s. 11.

7 Akcent toniczny języka starogreckiego w połączeniu ze specyfiką metrów wierszowych, nawet mało skomplikowanych, nadaje każdemu utworowi poetyckiemu swoistą melodyjność.

8 C.M. Bowra, Early Greek Elegists, London 1983, s. 6; A. Lesky, Geschichte der griechischen Literatur, Bern-München 19713², s. 129; M.L. West, Studies in Greek Elegy and Iambus, Berlin-New York 1974, s. 13-14; K. Bartol, Greek Elegy and Iambus ... , s. 46-51. Przeciwny pogląd reprezentują: D.A. Campbell, Flutes and Elegiac Couplets, „JHS” 1966, vol. 84, s. 63-68 oraz T.G. Rosenmeyer, Elegiac and Elegos, „Calif. Stud. in Class. Ant.” 1968, vol. 1, s. 217-231. 
nawet jeśli był nim autor, oraz akompaniatora jakiegoś przygotowania, które wykraczało poza doraźną improwizację. W konsekwencji elegia zyskiwała walor performatywny bez względu na liczebność odbiorców i okoliczności prezentacji. I tu dochodzimy do kwestii kontekstów sytuacyjnych przedstawiania poezji elegijnej. Nie ma żadnych wątpliwości co do dwóch okazji: symposion (względnie komos) i agon poetycki9. Podjęte przez badaczy próby rozszerzenia zakresu modeli sytuacyjnych, na przykład o wykonanie przed bitwą w czasie wojny, na oficjalnym zgromadzeniu na agorze, podczas uroczystości pogrzebowych ${ }^{10}$, spotkały się z zastrzeżeniem co do opacznej interpretacji starożytnych świadectw literackich, a także z zarzutem, że są rezultatem błędnego identyfikowania zawartości tematycznej utworu z okazją do jego wykonania ${ }^{11}$. W świetle uwagi o performatywnym charakterze elegii archaicznej trudno odmówić słuszności opinii Krystyny Bartol:

It must be remembered that the existence of some of the different types of elegy in the archaic period, distinguished each from the other because their differing content (i.e. sympotic, political, military, philosophical, historical and love elegies), does not mean that each category was presented at a separate occasion, strongly connected itself. This way of thinking will result in a false conclusion, something which is clearly visible in the case of elegies with a military subject-matter; the occasion for performing such elegies was, as it has been convincingly argued by Bowie, the symposium, not, as West believes, the moment just before a battle ${ }^{12}$.

Trzeba w tym miejscu wspomnieć o pewnym epizodzie z życia Solona przytaczanym przez starożytnych pisarzy (Plutarch, Żywot Solona 8; Polyainos, Strategmata 1, 20; Diogenes Laertios, Żywoty i poglądy słynnych filozofów I, 46-47) w związku z konfliktem między Atenami a Megarą o wyspę Salaminę. Zmęczeni długotrwałymi walkami z Megarą Ateńczycy wprowadzili zakaz, pod karą śmierci, agitowania na rzecz kontynuowania kampanii. Wówczas Solon miał skomponować poemat elegijny Salamina i, udając obłąkanego, wygłosić go publicznie na agorze. Zawarty w utworze żarliwy apel o podjęcie działań wojskowych przeciwko zaborczej Megarze miał odnieść pozytywny skutek - Ateny zdecydowały się na organizację następnej wyprawy zbrojnej. $Z$ całego utworu zachowało się osiem wersów, których interpretacja, zwłaszcza kontrowersyjnego pierwszego

9 Zob. K. Bartol, Greek Elegy and Iambus..., s. 56-57.

10 Martin L. West rozróżnił osiem typów sytuacyjnych dla wykonywania elegii; idem, Studies in Greek Elegy..., s. 10-13.

${ }^{11}$ Krytycznie do interpretacji Martina L. Westa odniósł się Ewen L. Bowie, który na postawie analizy tych samych tekstów źródłowych przekonująco dowodził dwóch możliwych kontekstów wykonawczych, czyli symposia i agony w czasie oficjalnych uroczystości; idem, Early Greek Elegy..., s. 21, 27.

${ }^{12}$ K. Bartol, Greek Elegy and Iambus..., s. 52. 
dystychu ${ }^{13}$, stanowi pole do dyskusji dla współczesnych badaczy, a równocześnie stawia pod znakiem zapytania wiarygodność starożytnych przekazów co do okoliczności prezentacji Salaminy na agorze. Oczywiście nie można całkowicie wykluczyć, że takie zdarzenie miało miejsce, ale byłby to ewenement ${ }^{14}$, ponieważ agora była miejscem wygłaszania mów politycznych prozą, a nie propagandowych popisów poetyckich, jakiegoś „dramatic performance” czy „poetry in action”, jak chce Bernard M.W. Knox ${ }^{15}$. Jest jednak bardzo prawdopodobne, że przekazywana przez starożytnych autorów historia stanowi przykład konstruowania wątku biograficznego wybitnej postaci na podstawie jej twórczości i dosłownego odczytania fragmentu poematu ${ }^{16}$. Poza tym warto zauważyć, że w całej starożytnej biografistyce daje się zaobserwować upodobanie do efektownych, czasami nawet efekciarskich, opowiadań przy stosunkowo małej dbałości o prawdę historyczną. Interesująca wzmianka, czasami zwykła plotka, mogła być powielana, modyfikowana, wzbogacana o nowe elementy, aż urastała do rozmiarów sensacyjnego wydarzenia. Takim z pewnością byłoby wystąpienie Solona, wybitnego, z punktu widzenia potomnych, męża stanu, który na jednej szali stawia swój honor - miał wszak wykonywać Salaminę, symulując chorobę psychiczną - na drugiej zaś patriotyzm i interesy współobywateli. Nasuwa się wątpliwość, czy ateński arystokrata z przełomu VII i VI wieku p.n.e. ryzykowałby dobre imię, narażał się na upokorzenie i pośmiewisko, czy w ogóle musiałby imać się takich demonstracyjnych posunięć dla osiągnięcia celu. Racjonalniejsze wydaje się wyjaśnienie, że Solon wystąpił przed Ateńczykami na oficjalnym zgromadzeniu z żarliwym agitacyjnym przemówieniem, a Salamina jest jego poetycką wersją, prezentowaną przy okazji symposion ${ }^{17}$.

Można $\mathrm{z}$ dużym prawdopodobieństwem przyjąć, że symposia stanowily najstosowniejszą okazję do prezentacji również innych utworów Solona. Wystarczy zdać sobie sprawę, czym w istocie był fenomen ówczesnych symposiów. Rzeczownik niefrasobliwie dziś tłumaczony jako „uczta”, wywołując tym samym

13 „Herold - sam z upragnionej przybywam tu Salaminy

Pieśń chcąc śpiewać rytmiczną, n i e n a a g o r z e przemawiać”.

Wszystkie cytaty utworów Solona przytaczane są w tłumaczeniu Włodzimierza Appela; Liryka starożytnej Grecji. Podkreślona w przekładzie fraza, w oryg. ả $v \tau^{\prime}$ ả $\gamma o p \tilde{\eta} s$, może być różnie interpretowana: „naprzeciw agory” (tzn. „naprzeciw ludzi zebranych na agorze”, czyli „na agorze”), „zamiast publicznego przemówienia”, „zamiast na agorze”; szczegółową analizę semantyczną przedstawia K. Bartol; eadem, Liryka grecka..., s. 261-262.

14 Nietypowość tej sytuacji podkreśla nawet Martin L. West - zwolennik podawanej przez antyczne testimonia wersji; idem, Studies in Greek Elegy..., s. 12-14.

15 B.M.W. Knox, Elegy and Iambus, [w:] The Cambridge History of Classical Literature, ed. P.E. Easterling, B.M.W. Knox, Cambridge 1987, s. 147.

16 Zob. K. Bartol, Greek Elegy and Iambus... , s. 54-55.

17 K. Bartol, Liryka grecka..., s. 161-162. 
konotacje gastronomiczne, oznaczał de facto instytucję społeczną, która sprzyjała kultywowaniu ideologii określonej grupy społecznej, czy wręcz stała na straży przestrzegania jej etosu ${ }^{18}$. Symposia, obok funkcji stricte rozrywkowej, stwarzały możliwość wymiany myśli, poglądów, podejmowania dyskusji, a nawet uprawiania propagandy. Brak innych środków komunikacji rekompensowała poezja wykonywana publicznie w trakcie bardziej lub mniej licznych spotkań. Wykonywana, podkreślmy, na ogół przez profesjonalnych śpiewaków ${ }^{19}$, których występy stanowily atrakcję intelektualno-rozrywkowej części symposiów, pełniąc tym samym rolę archaicznych „publikatorów”.

\section{Polityczna i poetycko-publicystyczna działalność Solona}

Naturalnie Solon był obserwatorem narastającego w Atenach społecznego napięcia. Jego ocena istniejącego stanu, dokonana bynajmniej nie z perspektywy przedstawiciela warstw uprzywilejowanych, jest wyrazem rzeczowego oglądu i głębokiej troski o losy ojczyzny (fr. 4 W.):

$5 \quad$ Własnym atoli szaleństwem to miasto zniszczyć wspaniałe pragną jego mieszkańcy, własnym zyskom powolni.

Myśl i ludu, i wodzów bezbożna; z powodu zaś wielkiej pychy niechybnie im przyjdzie liczne wycierpieć nieszczęścia $[\ldots]$

12 ani majątków świątynnych, ani publicznych nie szczędząc, każdy skądinąd kradzieżą przywłaszczyć sobie coś pragnie [...]

17 Oto już nieunikniona niedola ku miastu się zbliża, zmierza krokiem pośpiesznym czas nieszczęsnej niewoli, który wojnę domową i waśń drzemiącą obudzi -

20 ona dla wielu wyznaczy kres uroczej młodości; szybko bowiem za wrogów przyczyną niszczeje to lube miasto, gdy spory się toczą miłe dla ludzi występnych.

Takie zło śród ludzi się szerzy; więc wielu z biedaków swoją ojczyznę opuści w obcą sprzedanych krainę,

25 oni cierpieć niewolę będą w pętach haniebnych $[\ldots]$.

30 Serce mi każe o tym pouczyć Aten mieszkańców, jako że miastu najwięcej nieszczęść Bezprawie przynosi; gdzie Praworządność natomiast, tam wszystko stosowne i słuszne [...].

${ }^{18}$ Elegie zawarte $\mathrm{w}$ tak zwanym Corpus Theognideum dostarczają przykładów roli symposiów w kręgach arystokratycznych; zob. M. Vetta, Theognis. Elegiarum liber secundus, Roma 1980, s. XXXVI.

${ }_{19}$ Nie oznacza to bynajmniej, że sam autor nie mógł okazjonalnie prezentować swoich utworów. Najczęściej jednak, co jest typowe dla kultury oralnej, wchodzity one do repertuaru „zawodowych” wykonawców, którzy uświetniali swoimi występami symposia. 
Przywołany tu, z konieczności ze skrótami, fragment słynnej elegii o praworządności wykazuje trójdzielną kompozycję ze względu na zawartość tematyczną: przyczyny wewnętrznych konfliktów w Atenach, zagrożenie wojną domową, motywy parenetyczne. Winą za pogłębiający się kryzys poeta obarczył wszystkich Ateńczyków, wychodząc z przekonania, że postawy i czyny każdego obywatela $\mathrm{z}$ osobna wpływają na stan państwa, które jest ze swej natury tworzone przez jednostki. Pogoń obywateli za zyskiem, bez względu na stan posiadania, przedkładana jest nad dobro ogółu. W ludzkiej skłonności do pomnażania dóbr materialnych widział Solon zagrożenie dla ateńskiej polis. Partykularne interesy poszczególnych grup społecznych nieuchronnie prowadzą do wewnętrznych walk, których konsekwencje w mniejszym lub większym stopniu dotkną każdego. Sugestywny opis nieszczęść (śmierć w bratobójczej walce, tułaczka, niewola), spowodowanych chęcią zysku, lekceważeniem sprawiedliwości i burzeniem spolecznego porządku, stanowil dobitną przestrogę dla obywateli. Tę uzupełnił Solon o pochwałę personifikowanej praworządności (eunomia); wyliczając jej dobrodziejstwa, dowodzil, że tylko ona może stanowić remedium na nieszczęścia grożące państwu.

Elegia o praworządności była narzędziem polityki doświadczonego męża stanu i walki o zmianę państwowego status $q u o^{20}$. Ale jego żarliwy apel został zlekceważony. Konflikt narastał.

Wybrany archontem z nieograniczonym zasięgiem władzy na rok 594/593 Solon bez trudu mógł wprowadzić tyranię, która nie krępowałaby jego zamierzonych poczynań jednoroczną kadencją ${ }^{21}$. Nie chcial, jak twierdzi Plutarch, gardząc jedynowładztwem (Żywot Solona 14-15) ${ }^{22}$. Swoją rolę widział we wprowadzeniu reform społecznych, politycznych, a nawet gospodarczych. Wśród najważniejszych decyzji znalazło się umorzenie długów, tak zwana seisachtheia - „strząśnięcie długów” zaciągniętych przez zubożałych rolników. Z pól, które kiedyś stanowiły ich własność, a później przeszły w posiadanie wierzycieli, zniknęły kamienne słupy dłużnicze. Chłopi, którzy zadłużyli się pod zastaw swojej osoby, odzyskali wolność, także ci, którzy zostali sprzedani zagranicę. Nadto Solon wprowadził na przyszłość zakaz udzielania tego rodzaju pożyczek. Wolność uzyskali także

${ }^{20} \mathrm{Na}$ tę funkcję elegii zwrócił uwagę David A. Campbell; idem, Greek Lyric Poetry. A Selection of Early Greek Lyric, Elegiac and Iambic Poetry, London-Bristol 1982, s. 240.

${ }^{21}$ Starożytne źródła różnią się nieznacznie w sprawie datowania archontatu Solona. Próby wyjaśnienia tych rozbieżności zaowocowały hipotezami, które wydłużają okres sprawowania przez niego urzędu; reforma zniesienia długów miałaby odbywać się w 594/593 roku p.n.e., natomiast reformy polityczne wprowadzone zostałyby w 592/591 roku p.n.e.; zob. N.G.L. Hammond, The Seisachtheia and Nomothesia of Solon, „JHS" 1940, vol. 60, s. 71-83.

${ }^{22}$ Podobna ocena poczynań Solona znajduje się w Ustroju politycznym Aten Arystotelesa $(6,3)$. 
hektemoroi, ale bez prawa do dzierżawionych gruntów. Mogli natomiast swobodnie opuszczać Attykę i liczyć na przydział ziemi w nowo powstających koloniach ateńskich.

Eupatrydzi byli rozczarowani posunięciami Solona; liczyli bowiem, że jako rozjemca będzie reprezentował ich interesy. Tymczasem seisachtheia naraziła ich na straty wskutek umorzenia długów i odebrała w pewnym stopniu tanią siłę roboczą, chociaż de facto układ własności ziemskiej nie uległ zmianie, nie doszło bowiem do nowego podziału gruntów. Brak radykalnych kroków Solona w tym względzie wzbudził niezadowolenie chłopstwa - ci, którzy odzyskali wolność, nadal pozostawali bezrolni, a sytuacja bytowa pozostałych nie uległa polepszeniu.

Najistotniejszą reformą polityczną był podział obywateli na cztery klasy społeczne wedle posiadanego majątku. Przynależność do grup majątkowych pozostawała w ścisłym związku z możliwością sprawowania najwyższych urzędów w polis. Najważniejsi urzędnicy wybierani byli spośród najzamożniejszych obywateli. W ten sposób ukrócony został polityczny monopol starej arystokracji rodowej, a do głosu doszli bogacący się Ateńczycy spoza warstwy eupatrydów. Wszyscy obywatele wchodzili w skład ekklesia - zgromadzenia, do którego uprawnień należał wybór urzędników - wszyscy również mieli prawo odwoływać się od decyzji urzędników do sądów przysięgłych (heliaia), których przedstawiciele rekrutowali się z wszystkich grup społecznych pełnoprawnych obywateli.

Polityczne reformy Solona również nie spotkały się z powszechną akceptacją: niezadowolenie arystokracji wynikało z osłabienia jej prymatu, rozczarowanie ludu spowodowane było zachowaniem status quo, czyli niewielkim relatywnie znaczeniem politycznym ${ }^{23}$.

Według Arystotelesa (Ustrój polityczny Aten 11,1) Solon, wobec ataków rodaków i kontrowersji wokól jego praw, opuścił ojczyznę na dziesięć lat, odebrawszy od obywateli przysięgę, że żadne $\mathrm{z}$ nich nie zostanie $\mathrm{w}$ tym czasie zmienione ${ }^{24}$.

Nie jest możliwe ustalenie chronologii powstawania utworów, w których Solon broni swoich reformacyjnych posunięć przed krytyką obywateli. Nie wiadomo, czy tworzył poematy już na dobrowolnym wygnaniu, czy przed opuszczeniem Aten, a może jeszcze w trakcie sprawowania urzędu. Żadne testimonia nie dostarczają informacji, w jakim czasie po złożeniu archontatu Solon wyjechał

23 Szerzej o reformach Solona zob. B. Bravo, E. Wipszycka, Historia starożytnych Greków, s. 239-247; W. Lengauer, Starożytna Grecja okresu archaicznego i klasycznego, Warszawa 1999, s. 71-74.

24 Tę wersję powtarza Plutarch (Solon 25). Inną przyczynę wyjazdu Solona podaje Diogenes Laertios (Żywoty, Solon I, 50); opuszczenie Aten miało być spowodowane dojściem Pizystrata do władzy. 
z ojczystej polis. Można jedynie spekulować na podstawie logicznych przesłanek, że prezentacje publicystycznych poematów miały miejsce po opublikowaniu praw na ateńskiej agorze; jeden z fragmentów (fr. $36 \mathrm{~W}$.) przynosi sprawozdanie działalności politycznej i jej obronę przed atakami ze strony niezadowolonych współobywateli:

Niech obok sądu wieków przyszłych świadkiem będzie

Najpotężniejsza macierz bogów olimpijskich,

$5 \quad$ Najlepsza także, Ziemia czarna, z której niegdyś

Dłużnicze słupy zniosłem wszędy powbijane,

I ją, znękaną przedtem, wolną uczyniłem.

Z powrotem do ojczystych Aten, bogów dzieła,

Przywiodłem wielu: tych sprzedanych zgodnie z prawem,

10 I tych bezprawnie, oraz tych, co z niemożności

Spłacenia długów, uciekali, już nie pomnych

Attyckiej mowy, bowiem wszędy się tułali.

I tu na miejscu niegodziwie zniewolonych,

Co obawiali się zachcianek swego pana,

15 Wolnością obdarzyłem; to zdziałałem,

Złączywszy w jedno siłę oraz sprawiedliwość.

Zrobiłem i spełniłem to, co przyrzekałem,

Tak samo dobrym, jak i podłym ${ }^{25}$ dałem prawa,

Złączywszy wszystkich ładem sprawiedliwym.

20 A gdyby inny ktoś, jak ja, pochwycił oścień,

Ktoś nierozumny, człowiek żądny bogactw,

Nie zdołałby powstrzymać ludu; gdybym tego,

Co lud dla swoich przeciwników, pragnął,

Lub tego, co ludowi gotowali tamci,

25 To miasto wielu by straciło mężów. [...]

W poetyckim sprawozdaniu, przynajmniej w jego zachowanej części ${ }^{26}$, Solon koncentruje się na swoich dwóch dokonaniach: umorzeniu długów (seisachtheia) najuboższej części obywateli i zapobieżeniu wojnie domowej. Jakby mimochodem mówi o wprowadzeniu timokracji przy podziale urzędów państwowych (w. 18). Środkiem do osiągnięcia celów obiecanych społeczeństwu ateńskiemu była konsekwencja $\mathrm{w}$ działaniu i stosowanie zasad sprawiedliwości, bez

25 Stosowana przez Solona terminologia ma wymowę socjo-polityczną, a nie etyczną; „dobry” oznacza przynależność do wyższej klasy, „podły” pochodzenie z nizin społecznych.

26 Przytoczony tu, z pominięciem dwóch pierwszych i dwóch ostatnich wersów, fragment poematu zawdzięczamy Arystotelesowi, który cytuje go w Ustroju politycznym Aten $(12,3)$ przy okazji omawiania reform Solona. 
uciekania się do radykalnych działań. Jak zauważa Krystyna Bartol: „utwór Solona nie jest jedynie suchym wyliczeniem wprowadzonych przez niego zmian, lecz żarliwą obroną wszystkich posunięć” ${ }^{27}$.

Należy nadto zwrócić uwagę na mało czytelny dla dzisiejszego odbiorcy, polemiczny charakter utworu. Manifestuje się on przede wszystkim w zastosowanym metrum - trymetrze jambicznym. Nawiasem mówiąc, metrum to eliminuje utwór z kategorii elegii, którą starożytni klasyfikowali na podstawie wyróżnika formalnego, jakim był dystych elegijny. Utwory w metrach jambicznych tradycyjnie cechowała zawartość krytyczna i polemiczna. Terminologia sądowa, która zawiera się w wezwaniu świadków (w. 3-5) przedsięwziętych działań, również sugeruje wymowę poematu krytyczną wobec politycznych antagonistów. Wskazane środki wyrazu świadczą o publicystycznej funkcji utworu, który można uznać za poetycką wersję publicznego przemówienia Solona w obronie swoich działań reformatorskich.

Tę samą rolę spełniała zapewne elegia (fr. 5 W.), którą przytacza Plutarch w Żywocie Solona (12) przy okazji omawiania reform politycznych regulujących stosunki między dwiema grupami społeczeństwa - eupatrydami, którzy wcześniej sprawowali wszystkie urzędy, i ludem:

Bowiem tyle, co trzeba, ludowi władzy przyznałem, ani mu czci nie ujmując, ani nie dając zbyt wiele;

tym zaś, co władzę dzierżyli i podziw budzili majątkiem, też nakazałem się wyzbyć tego, co z hańby się bierze.

5 Tarczą mocną i jednych, i drugich chroniąc stanąłem, żadnej stronie nie dałem niesprawiedliwie zwyciężyć.

Zacytowany fragment daje świadectwo rozsądku i realizmu politycznego Solona, który dobrze zdawał sobie sprawę z niedojrzałości prostego ludu do większego udziału we władzy, rozumial, że jest, jak zauważa Anna M. Komornicka, „duchowo prymitywny, chwiejny, niezdolny do szerszego spojrzenia poza interes osobisty i żądzę odwetu" 28 . Wiedział jednak, że ateński demos, doprowadzony do ostateczności w poczuciu krzywdy i rażącej niesprawiedliwości, stanowi potężną siłę zdolną nie tylko szukać zemsty na klasie bogaczy, ale także zburzyć wewnętrzny pokój.

Jednym z powodów niezadowolenia eupatrydów z działań Solona było zaniechanie przez niego zaprowadzenia $w$ Atenach tyranii. Mieli oni bowiem nadzieję, że reformy przybiorą nieledwie rozmiary fasadowe, a posłuszeństwo ludu uda się utrzymać rządami twardej ręki. Solon jednak nie chciał wdrażać zmian

27 K. Bartol, Liryka grecka..., s. 316.

28 A.M. Komornicka, Poezja starożytnej Grecji. Wybrane gatunki literackie, Łódź 1987, s. 122. 
w oparciu o jedynowładztwo, gdyż ten system władzy sprzeciwiał się jego wizji porządku społecznego. Replika na krytykę politycznych oponentów została zawarta w jednym z utworów (fr. 32 W.):

...jeślim zważał na ojczyznę,

a wzgardziwszy siłą srogą nie sięgnąłem po tyranię,

aby sławy nie pohańbić i nie splamić; to niczego

5

się nie wstydzę, mniemam bowiem, że w ten sposób się okażę

lepszym niźli inni ludzie

Można ubolewać, że z całego poematu zachował się krótki uszkodzony fragment, jednakże już w tak szczupłym materiale literackim dają się dostrzec cechy felietonu: nawiązanie do aktualnych wydarzeń $w$ tonie polemicznym i z akcentami osobistymi ${ }^{29}$. Sprawozdawczy charakter, obecny w wyżej przytoczonych utworach, ustępuje tutaj miejsca subiektywizmowi w ocenie sytuacji i refleksjom natury moralnej. Warto przy okazji przywołać jeszcze jeden fragment o charakterze felietonu, tym razem o zabarwieniu ironicznym (fr. $33 \mathrm{~W}$.):

Niezbyt mądrym się okazał Solon ani niezbyt rozsądnym, bowiem wcale nie skorzystał, kiedy bóg mu szczęście dawał. Chociaż wielką sieć zarzucił i go połów aż zadziwił, nic dla siebie nie wyciągnął wraz z rozsądkiem tracąc głowę.

5 Gdybym ja był przejął władzę, wziąłbym bogactw moc niezmierną, choćbym tylko jednodniowym miał w Atenach być tyranem; później niechby darli skórę ze mnie, niechby sczezł i ród mój.

Zastosowany tu chwyt kompozycyjny, polegający na przytoczeniu wypowiedzi ex mente aliena, czyli osoby innej od odautorskiego "ja”, zręcznie potęguje wymowę utworu, krytyczną wobec bezzasadnych, z punktu widzenia poety, zarzutów stawianych mu przez politycznych adwersarzy. Pozorna autoironia jest $d e$ facto polemiką zmieszaną z pobłażliwym politowaniem dla ich niepohamowanej chciwości; oponenci Solona stali się w ten sposób przedmiotem finezyjnie wyrażonej kpiny.

Zarówno forma (metra jambiczne), jak i treść ewokowanego fragmentu sugerują, że jego prezentacje odbywały się w relatywnie kameralnych okolicznościach sympozjalnych i że w tym przypadku raczej nie mamy do czynienia z poetyckim wariantem oficjalnego przemówienia publicznego.

Partykularne interesy różnych warstw społeczeństwa położyły się cieniem na przemianach wprowadzonych przez ustawodawcę i sprawily, że nowy

29 Zob. K. Tatarowski, Felieton, [hasło w:] Słownik rodzajów i gatunków literackich, s. $335-338$. 
porządek okazał się niestabilny. Społeczeństwo ateńskie rozbiło się na trzy frakcje, z których każda reprezentowała odmienny program polityczny: ziemiańskie rody eupatrydów (pediakoi) domagały się obalenia reform Solona; średnio zamożne chłopstwo i rzemieślnicy (paralioi), pod przewodnictwem arystokraty ze starego rodu Alkmenoidów, Megaklesa, optowali za ich utrzymaniem; najbardziej radykalne ugrupowanie (hyperakrioi), na czele którego stanął arystokrata Pizystrat, postulowało natomiast programowo nowy podział ziemi. Jak widać, u podstaw rozłamu społeczno-politycznego Attyki leżały aspiracje ambitnych jednostek wywodzących się z arystokracji, które pretendowały do wprowadzenia jedynowładztwa, zręcznie manipulując szerokimi rzeszami obywateli. Ateny stały się areną nieustannie wybuchających konfliktów i ostrych walk wewnętrznych, które skutecznie destabilizowały porządek społeczny.

Solon, który boleśnie musiał odczuwać fiasko swoich wysiłków sprzed blisko trzydziestu lat, starał się ostrzec ludność Aten przed zakusami demagogów. Ślady tej ostatniej aktywności politycznej wybitnego męża stanu odnajdujemy w zachowanych fragmentach elegijnych (fr. 9 W.):

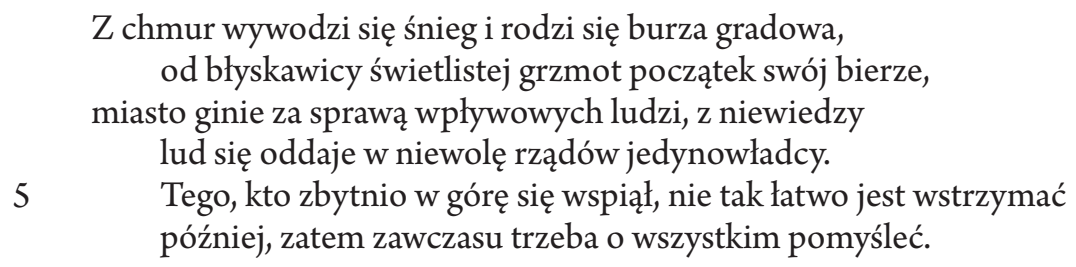

Na podstawie trzech dystychów nie można z całą stanowczością stwierdzić, czy w całym utworze dominowały akcenty parenetyczne, czy też zawierał więcej elementów ekshortacyjnych, wykraczających poza pouczenie zawarte w wersie 6 o konieczności rozważnego podejmowania decyzji, z uwzględnieniem potencjalnych konsekwencji, od których może nie być odwrotu. Poetycka paralela z niebezpiecznymi zjawiskami atmosferycznymi wzmaga siłę przestrogi przed zakusami „wpływowych ludzi”, którzy - pod pozorem reprezentowania interesów ludu - uzurpują sobie prawa do władzy absolutnej. Niestety, ateński demos poddał się tej politycznej mistyfikacji, nie umiejąc wyciągnąć właściwych wniosków z rozgrywających się wydarzeń.

Autorzy starożytni cytują fragmenty tej elegii w kontekście sprzeciwu Solona wobec dążeń Pizystrata do wprowadzenia tyranii30. Według świadectwa Plutarcha poeta miał wygłosić na agorze mowę, której treść zgadza się z wydźwiękiem

${ }^{30}$ Diodor Sycylijski, Bibliotheca historica, 9, 20; Diogenes Laertios, Żywoty i poglądy stynnych filozofów, 1, 50. 
tego utworu (Żywot Solona 30): „Solon był już bardzo stary i nie miał poparcia, a jednak wystąpił na agorze i przemówił do obywateli, zarzucając im tchórzostwo i brak rozsądku i namawiając gorąco, by nie pozbawiali się wolności. Wtedy powiedział pamiętne słowa, że wcześniej łatwiej można było powstrzymać rodzącą się tyranię, teraz, kiedy już powstała, obalić ją trudniej, ale z większą chwałą”.

Arystoteles (Ustrój polityczny Aten 14, 2) i Plutarch (Żywot Solona 30) opowiadają zgodnie o pewnym epizodzie związanym z zabiegami Pizystrata; miał się sam okaleczyć, oskarżyć o zamach przeciwników i domagać się od zgromadzenia przyznania mu straży przybocznej dla ochrony. Mimo sprzeciwu Solona wniosek został uchwalony. Niebawem Pizystrat przy pomocy swojej przybocznej gwardii opanował Akropol, co faktycznie wiązało się z przejęciem władzy. Echa tego wydarzenia brzmią w elegii pełnej wyrzutu skierowanego do współobywateli (fr. 11 W.):

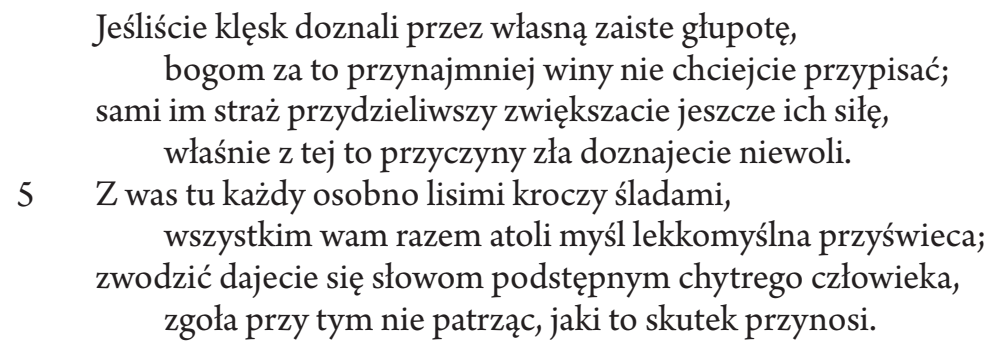

Jeśli przyjąć świadectwo Plutarcha, że Solon napisał tę elegię po wycofaniu się z życia politycznego (Żywot Solona 30), wypada skonstatować, że przeznaczona była do prezentacji przy okazji symposiów. Apostrofa do całego ateńskiego społeczeństwa może być w tym wypadku uznana za konsekwencję uniwersalnego charakteru gatunku ${ }^{31}$.

W całej zachowanej twórczości Solona dominuje refleksja parenetyczna, jednak w utworach publicystycznych o tematyce politycznej zdaje się ona przybierać na sile, bowiem moralność i polityka u poety ściśle się splatają. Przyczyn takiego stanu rzeczy należy upatrywać przede wszystkim w poglądach Solona, w wyznawanym przez niego systemie wartości: szczerym patriotyzmie, umiłowaniu praworządności, poszanowaniu człowieka, tolerancji na odmienne zapatrywania itp. Nie bez znaczenia pozostaje również, właściwa mentalności starożytnych Greków, tradycyjnie przypisywana poetom funkcja społeczna. Przekonanie, że poeci są głosicielami woli bogów, dzięki talentowi będącemu boskim darem predestynowani do roli nauczycieli moralności; poeta-mędrzec, przez niebian

${ }^{31}$ Zob. K. Bartol, Greek Elegy and Iambus..., s. 60. 
natchniony, miał poprzez swoją twórczość dzielić się z ludźmi mądrościąa ${ }^{32} . \mathrm{Z}$ powodu autorytetu, jakim cieszył się Solon poeta, jego poglądy, ubrane w artystyczną formę, miały szansę zyskać większą siłę przekazu niż wygłoszona publicznie mowa wśród gwarnego tłumu na agorze. Nie zmienia tego fakt, że prezentowane na symposiach trafiały do mniejszego audytorium. Częstotliwość wykonywania poematów mogła z powodzeniem rekompensować szczuplejszy jednorazowo krąg odbiorców. Można z dużym prawdopodobieństwem przyjąć, że utwory znanego w mieście poety, a poza tym znakomitej postaci z życia publicznego, krążyły wśród obywateli i były bardzo dobrze znane. $\mathrm{Z}$ tych względów realizowały $\mathrm{z}$ powodzeniem funkcję publicystyczną, w tym ekshortacyjną i parenetyczną, oraz propagandową ${ }^{33}$.

Solon nie był pierwszym elegikiem, który uczynił z poezji instrument propagandy. Przed nim zaznaczyli się w tej dziedzinie Kallinos i Tyrtajos; Kallinos w elegiach-apelach mobilizujących rodaków do walki w obronie rodzinnego Efezu, Tyrtajos w elegiach bitewnych, sankcjonujących prawa Lacedemonu do hegemonii na Peloponezie i propagujących spartański model życia. Ateński prawodawca natomiast był pierwszym, wedle naszej wiedzy, który ze względu na głębokie zaangażowanie w sprawy państwowe ojczystej polis zawarł w swojej poezji przekaz publicystyczny, spajający wymiar polityczny i etyczny w nierozerwalną całość.

32 A.M. Komornicka, Pindar i Platon o roli poetów i poezji, „Sprawozdanie z Czynności i Posiedzeń Naukowych ŁTN”1980, R. XXXIV, nr 1, s. 1.

33 Ta funkcja elegii archaicznej na przykładzie twórczości Tyrtajosa została szczegółowo przebadana przez J.H. Sheya; idem, Tyrtaeus and the Art of Propaganda, „Arethusa” 1976, vol. 9, s. 5-28. 


\section{BIBLIOGRAFIA}

Adamczewska I., Elegia, [hasło w: ] Stownik rodzajów i gatunków literackich, red. G. Gazda, Warszawa 2012.

Bartol K., Greek Elegy and Iambus. Studies in Ancient Literary Sources, Poznań 1993.

Bartol K., Liryka grecka. Wybór tekstów i komentarz, t. I: Jamb i elegia, Warszawa-Poznań 1999.

Bowie E.L., Early Greek Elegy. Symposium and Public Festival, „JHS” 1986, vol. 106.

Bowra C.M., Early Greek Elegists, London 1983.

Bravo B., Wipszycka E., Historia starożytnych Greków, t. I, Warszawa 1988.

Campbell D.A., Flutes and Elegiac Couplets, „JHS” 1964, vol. 84.

Campbell D.A., Greek Lyric Poetry. A Selection of Early Greek Lyric, Elegiac and Iambic Poetry, London-Bristol 1982.

Hammond N.G.L., The Seisachtheia and Nomothesia of Solon, „JHS” 1940, vol. 60.

Knox B.M.W., Elegy and Iambus, [w:] The Cambridge History of Classical Literature, ed. P.E. Easterling, B.M.W. Knox, Cambridge 1987.

Komornicka A.M., Pindar i Platon o roli poetów i poezji, „Sprawozdanie z Czynności i Posiedzeń Naukowych ŁTN” 1980, R. XXXIV, nr 1.

Komornicka A.M., Poezja starożytnej Grecji. Wybrane gatunki literackie, Łódź 1987.

Lengauer W., Starożytna Grecja okresu archaicznego i klasycznego, Warszawa 1999.

Lesky A., Geschichte der griechischen Literatur, Bern-München $1971^{3}$.

Liryka starożytnej Grecji, oprac. J. Danielewicz, Wrocław 1984.

Rosenmeyer T.G., Elegiac and Elegos, „Calif. Stud. in Class. Ant.” 1968, vol. 1.

Shey J.H., Tyrtaeus and the Art of Propaganda, „Arethusa” 1976, vol. 9.

Tatarowski K., Felieton, [hasło w:] Stownik rodzajów i gatunków literackich, red. G. Gazda, Warszawa 2012.

Vetta M., Theognis. Elegiarum liber secundus, Roma 1980.

West M.L., Studies in Greek Elegy and Iambus, Berlin-New York 1974.

Wolski J., Historia powszechna. Starożytność, Warszawa 1972. 